Research Article

\title{
The Correlation and Regression Analysis of Physicochemical Parameters of River Water for the Evaluation of Percentage Contribution to Electrical Conductivity
}

\author{
Arun Kumar Shrestha ${ }^{1}{ }^{1}$ and Nabin Basnet ${ }^{2}$ \\ ${ }^{1}$ Department of Physics, Damak Multiple Campus, Jhapa, Nepal \\ ${ }^{2}$ Department of Chemistry, Damak Multiple Campus, Jhapa, Nepal \\ Correspondence should be addressed to Arun Kumar Shrestha; arundmk1010@gmail.com
}

Received 20 January 2018; Revised 21 May 2018; Accepted 12 June 2018; Published 24 July 2018

Academic Editor: Samuel B. Dampare

Copyright (c) 2018 Arun Kumar Shrestha and Nabin Basnet. This is an open access article distributed under the Creative Commons Attribution License, which permits unrestricted use, distribution, and reproduction in any medium, provided the original work is properly cited.

\begin{abstract}
Ten different water samples were collected from Ratuwa River and its tributaries. The laboratory test was carried out by standard procedures (APHA methods), and the measured values were compared with the Nepal standard recommended by Nepal Drinking Water Quality Standards (NDWQS). Statistical analysis also had been used to calculate the correlation coefficients and to plot the regression equations of various parameters with electrical conductivity. The aim of the study was to identify the parameters that affect the electrical conductivity and evaluate the percentage contribution of these parameters. The correlation matrix shows that color, total dissolved solids (TDS), chloride (Cl), fluoride (F), total phosphorus (TP), total alkalinity (TA), calcium (Ca), magnesium $(\mathrm{Mg})$, sodium $(\mathrm{Na})$, and dissolved oxygen (DO) have a significant effect on the electrical conductivity (EC). Among these parameters, TDS has the highest contribution (39.65\%) followed by total alkalinity (23.5\%), total hardness (19.9\%), chlorine (6.5\%), and calcium (5.5\%) ions, respectively. However, color, TP, fluoride, and DO have almost $1.45 \%$ contribution to the electrical conductivity.
\end{abstract}

\section{Introduction}

River water is an important source to provide the daily need of the fresh water for drinking and other purposes $[1,2]$. However, such sources of fresh water are gradually contaminated due to domestic, municipal, and industrial effluents and severely damaging the equilibrium condition between the environment and aquatic system. Contaminated water is a great concern all over the world as it is related to the health hazards [3].

The cheapest and best option to examine the pollution status of water is to calculate its electrical conductivity, and its value depends upon the concentration of impurities, mobility, and temperature of the solution [4-8]. For the industrial application, distilled water is categorized into ultrapure, pure, and regular depending upon the portion of impurities, [9] and it should have a fairly constant range of conductivity for a particular purpose. Therefore, any significant change in conductivity from the desired limit is also an indication of possible contamination so that precautions can be taken by monitoring it regularly. The conductivity measurement is also fairly used in leak detection, clean in place (CIP), desalination, detection of the interface of two liquid, and safety measure in the fuel industry. It also demonstrates the relationship between soil conditions, drought, rainfall, and other environmental situations that affect the production of crops $[10,11]$.

Nepal being a Himalayan country, numerous investigations have been carried out all over the country to access the quality of water by analyzing the physicochemical and microbial parameters of the major river basins [12-18]. In recent years, statistical tools such as correlation and regression analyses also have been extensively used for evaluating, monitoring, and predicting the concentration of impurities in water [19-24]. But, no such works have been obtained in the literature, especially in Jhapa-based rivers of 
eastern Nepal. These rivers are still untouched for the scientific purposes (research). The Ratuwa River and its tributaries are one of them of which even physicochemical analysis has not been conducted to access the water quality. Similarly, Damak is one of the rapidly growing cities where an industrial park is going to be established near a bank of Ratuwa in around 960 acres so that such type of work will be useful for the future purpose. In the present work, we are not only analyzing and interpreting the hydrochemical parameters in terms of their chemical properties, but also evaluating the percentage contribution to the electrical conductivity of Ratuwa River using statistical techniques. Such type of work is very useful to recognize the contaminants without detailed investigation of physicochemical parameters and makes it easy and simple in the water treatment process.

\section{Materials and Methods}

2.1. Sample Collection. Damak is situated between $26^{\circ} 35^{\prime} 21.28^{\prime \prime} \mathrm{N}$ to $26^{\circ} 44^{\prime} 58.71^{\prime \prime} \mathrm{N}$ latitude and $87^{\circ} 39^{\prime} 9.40^{\prime \prime} \mathrm{E}$ to $87043^{\prime} 10.32^{\prime \prime} \mathrm{E}$ longitude in the southeastern Terai region of Nepal with $130 \mathrm{~m}$ in elevation. It has a subtropical monsoon climate with summer temperatures ranging from $32^{\circ} \mathrm{C}$ to $35^{\circ} \mathrm{C}$, winter temperatures ranging from $8^{\circ} \mathrm{C}$ to $15^{\circ} \mathrm{C}$, and an average annual rainfall of $270 \mathrm{~mm}$ [25]. Damak shares its eastern and western boundaries with Ratuwa and Mawa rivers, northern boundary with Siwalik Hills of Ilam district, and southern boundary with the intersection of Ratuwa River and Mawa River. Ratuwa River and its tributaries, namely, Haat Khola, Dipeni, Betani, and Dhukure, were selected for the sample collection to highlight the pollution status of water. Among these perennial rivers, Ratuwa originates from the Siwalik Hill and rest of them originates from wetlands a few kilometers away from the sample collection sites. Dipeni and Haat Khola pass through the city collecting the domestic and municipal wastes, whereas Betani and Dhukure Khola (river) pass outside the city collecting the agricultural wastes.

In the first phase, the sample was collected on the 11th of May 2017 and second phase data were also collected on the 16th of April 2018 from the same spot. The sampling sites and the location of the study area are shown in Figure 1.

First, the sampling bottles (one-liter plastic bottle) were rinsed before sampling, sealed tightly after collection, and labeled in the spot. The samples were taken by pumping from a depth of $5-10 \mathrm{~cm}$ below to avoid contamination from the surface of the river basin [26] and were brought to Nepal Batawaraniya Sewa Kendra, Biratnagar for the laboratory test where forty-nine different parameters had been measured from standard procedures (APHA methods). In the first phase, the measured parameters were color, turbidity, $\mathrm{pH}$, electrical conductivity (EC), temperature, total solids (TS), total dissolved solids (TDS), total suspended solids (TSS), ammonia, chloride $(\mathrm{Cl})$, residual chlorine, fluoride $(\mathrm{F})$, sulphate, sulphide, silica, nitrite, nitrate, total nitrogen, total phosphorus (TP), soluble phosphorus, total hardness (TH), calcium hardness, acidity, carbon dioxide, total alkalinity (TA), aluminum, arsenic, cadmium, calcium $(\mathrm{Ca})$, total chromium, hexavalent chromium, cobalt, iron, lead, manganese, nickel, magnesium ( $\mathrm{Mg})$, oil and grease, potassium, sodium, zinc,
BOD, COD, dissolved oxygen (DO), total plate count, total coliform, faecal coliforms, faecal Streptococcus, and cyanide, respectively. In the second phase, color, $\mathrm{pH}$, EC, TDS, TSS, chloride, fluoride, sulphate, nitrate, TP, TH, TA, calcium, iron, manganese, magnesium, potassium, sodium, and DO were measured. Among these, result of twelve physicochemical parameters (EC and strongly correlated parameters with EC) and their statistical summaries with units and measuring techniques are depicted in Tables 1 and 2, respectively.

2.2. Data Analysis. To get an idea about the parameters that influence the electrical conductivity of water, firstly, the correlation matrix of 49 parameters was constructed (not shown). From the matrix, tentative parameters that affect the EC were identified keeping the significant level below $10 \%$. On the basis of this result, again, five water samples were taken from the same sites as we had taken previously and measured only nineteen selected parameters to control the risk of misleading results and conclusion. Finally, a correlation matrix was again constructed from these parameters which were significantly correlated with EC with a significant level below $10 \%(p<0.1)$ and it is shown in Table 3 . From the given data, a linear best fit was drawn between EC and other in which EC was considered as an independent variable and other as a dependent variable. With the help of slope and intercept in the linear best fit line, a linear regression equation was formulated for each parameter. The linear regression equation and its percentage contribution to EC are shown in Table 4.

\section{Results and Discussions}

3.1. Physicochemical Analysis. Among the measured parameters, only significantly correlated parameters with the electrical conductivity were discussed and the measured value was compared with the Nepal standards.

Color is one of the most important physical parameters of water, and it is due to the presence of dissolved impurities and waste materials. The color of water ranged from 0.78 to 7 Hazen with standard deviation (SD) of 2.02. The minimum value was in Ratuwa in the first phase and maximum in the second phase of Haat Khola. According to NDWQS guideline, the color of water of 5 Hazen is more desirable but color till 15 Hazen is acceptable for drinking purpose [27]. The average value of electrical conductivity in Ratuwa, Haat Khola, Dipeni, Betani, and Dhukure was 171.1, 472.5, 308.9, 225.9, and $123.7 \mu \mathrm{s} / \mathrm{cm}$, respectively. The higher values of Haat Khola and Dipeni showed the excessive presence of the domestic and municipal wastes. However, all these values were within the maximum concentration limit $(1500 \mu \mathrm{s} / \mathrm{cm})$ prescribed by NDWQS.

Total dissolved solids are natural pollutants in the river water and it imparts the color, total alkalinity, and conducting nature of water. The most desirable value of TDS is $500 \mathrm{mg} / \mathrm{L}$. However, the optimum value of $1000 \mathrm{mg} / \mathrm{L}$ is acceptable according to NDWQS guideline. The maximum and minimum TDS were recorded in Haat Khola $(256.5 \mathrm{mg} / \mathrm{L})$ and Dhukure $(59.95 \mathrm{mg} / \mathrm{L})$ during the first phase of our sample 


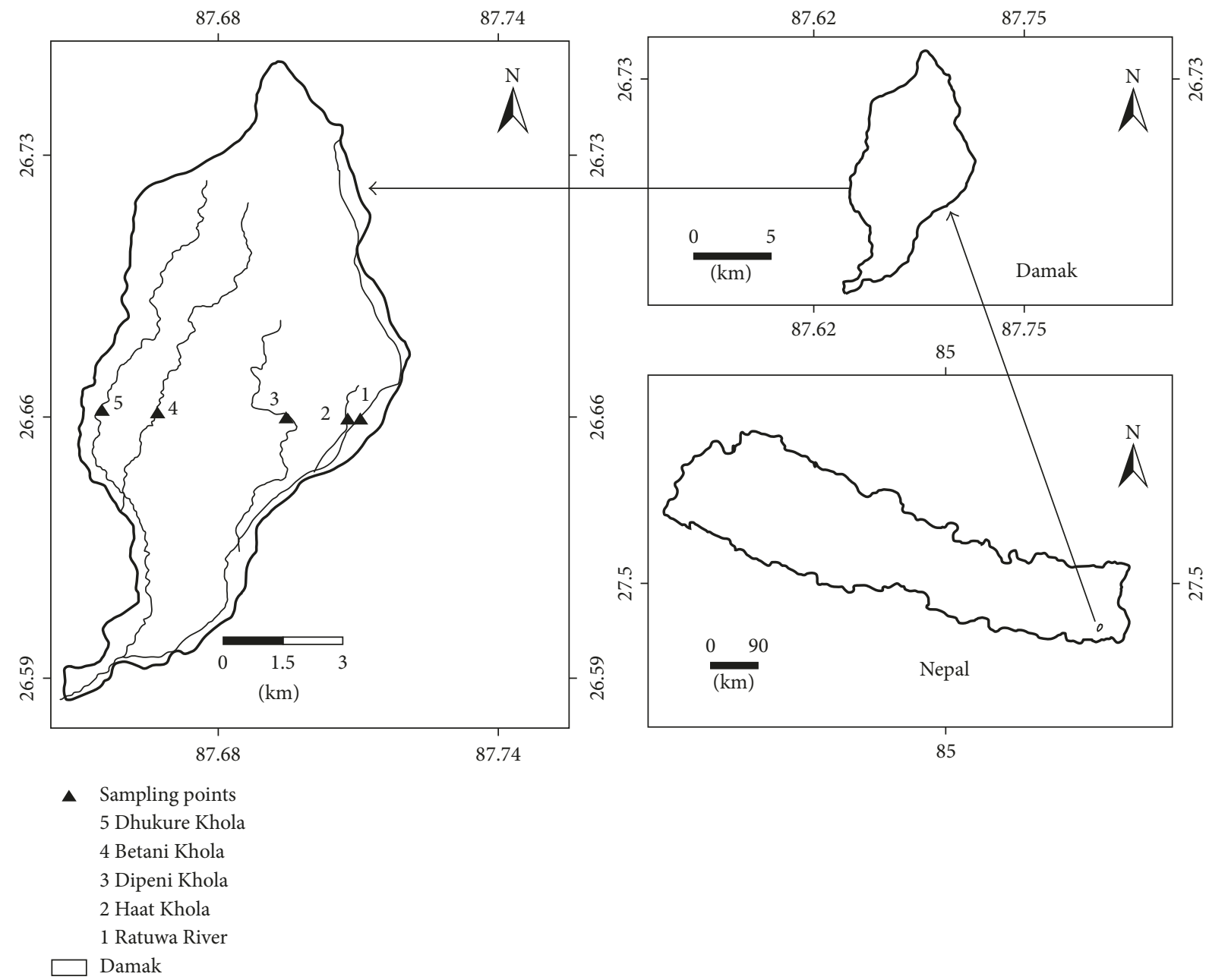

FIgURE 1: Location of the study site showing the sampling points inserted in the map of Nepal.

TABLE 1: Analysis of physicochemical parameters of different rivers in Damak with their units.

\begin{tabular}{|c|c|c|c|c|c|c|c|c|c|c|c|c|}
\hline \multirow{2}{*}{ SN } & \multirow{2}{*}{ Parameters } & \multirow{2}{*}{ Unit } & \multicolumn{2}{|c|}{ Ratuwa River } & \multicolumn{2}{|c|}{ Haat Khola } & \multicolumn{2}{|c|}{ Dipeni Khola } & \multicolumn{2}{|c|}{ Betani Khola } & \multicolumn{2}{|c|}{ Dhukure Khola } \\
\hline & & & 1st phase & 2nd phase & 1st phase & 2nd phase & 1st phase & 2nd phase & 1st phase & 2nd phase & 1st phase & 2nd phase \\
\hline 1 & Color & Hazen & 0.78 & 1.5 & 3.82 & 7 & 2.11 & 4 & 0.81 & 4 & 0.91 & 1.5 \\
\hline 2 & EC & $\mu \mathrm{s} / \mathrm{cm}$ & 134.6 & 207.8 & 513 & 432 & 259.7 & 358 & 138.8 & 313 & 119.9 & 127.4 \\
\hline 3 & TDS & $\mathrm{mg} / \mathrm{L}$ & 67.3 & 103.9 & 256.5 & 216 & 129.85 & 179 & 69.4 & 156.5 & 59.95 & 63.7 \\
\hline 4 & $\mathrm{Cl}$ & $\mathrm{mg} / \mathrm{L}$ & 7 & 13 & 49 & 36.98 & 16 & 20 & 12 & 19 & 13 & 5 \\
\hline 5 & $\mathrm{~F}$ & $\mathrm{mg} / \mathrm{L}$ & 0.17 & 0.13 & 0.25 & 0.32 & 0.2 & 0.18 & 0.13 & 0.23 & 0.05 & 0.17 \\
\hline 6 & $\mathrm{TP}$ & $\mathrm{mg} / \mathrm{L}$ & 0.28 & 0.06 & 1.43 & 1.07 & 0.43 & 0.9 & 0.13 & 0.79 & 0.12 & 0.05 \\
\hline 7 & $\mathrm{TH}$ & $\mathrm{mg} / \mathrm{L}$ & 65 & 63 & 119 & 113 & 75 & 97 & 35 & 84 & 31 & 15 \\
\hline 8 & TA & $\mathrm{mg} / \mathrm{L}$ & 136 & 88.4 & 152 & 139.4 & 95 & 117.4 & 56 & 110.5 & 94 & 22.1 \\
\hline 9 & $\mathrm{Ca}$ & $\mathrm{mg} / \mathrm{L}$ & 25.14 & 14.03 & 45.6 & 22.04 & 26.47 & 23.61 & 11.34 & 17.63 & 10.01 & 12.81 \\
\hline 10 & $\mathrm{Mg}$ & $\mathrm{mg} / \mathrm{L}$ & 1.94 & 6.56 & 5.88 & 8.12 & 3.64 & 7.63 & 2.18 & 6.48 & 1.94 & 1.7 \\
\hline 11 & $\mathrm{Na}$ & $\mathrm{mg} / \mathrm{L}$ & 7.41 & 6.23 & 16.38 & 13.06 & 9.86 & 6.76 & 11.58 & 10.86 & 4.43 & 6.56 \\
\hline 12 & DO & $\mathrm{mg} / \mathrm{L}$ & 6.67 & 2.76 & 2.08 & 3.06 & 5 & 2.96 & 5.83 & 2.86 & 6.67 & 2.86 \\
\hline
\end{tabular}

collection. A higher value of TDS is generally harmful to those who are a victim of kidney and heart diseases [28].

The chloride ion is an important constituent and found in water from natural as well as anthropogenic activities. Average value of chloride content of five river samples ranged between $9 \mathrm{mg} / \mathrm{l}$ to $42.99 \mathrm{mg} / \mathrm{L}$. These values are relatively low as compared to the Nepal standard $(250 \mathrm{mg} / \mathrm{L})$ and show that water is less contaminated by the chloride.

The main sources of phosphorus in water are agricultural fertilizers, manure, organic wastes, and industrial effluent, and it enters into the water from soil erosion, urban, and agricultural settings. It provides the nutrient for the growth 
TABLE 2: Statistical summary of the measured parameters of 10 water samples from Ratuwa, Haat Khola, Dipeni, Betani, and Dhukure Khola.

\begin{tabular}{|c|c|c|c|c|c|c|c|c|}
\hline Parameters & Units & Data points & Mean & $\mathrm{SD}$ & Sum & Min. & Max. & Method \\
\hline Color & Hazen & 10 & 2.643 & 2.02 & 26.43 & 0.78 & 7 & APHA-2510 \\
\hline Conductivity & $\mu \mathrm{s} / \mathrm{cm}$ & 10 & 260.42 & 139.98 & 2604.2 & 119.9 & 513 & APHA-2120c \\
\hline TDS & $\mathrm{mg} / \mathrm{L}$ & 10 & 130.21 & 69.99 & 1302.1 & 59.95 & 256.5 & APHA-2540 C \\
\hline Chloride & $\mathrm{mg} / \mathrm{L}$ & 10 & 19.098 & 13.72 & 190.98 & 5 & 49 & APHA-2500 B \\
\hline Fluoride & $\mathrm{mg} / \mathrm{L}$ & 10 & 0.183 & 0.074 & 1.83 & 0.05 & 0.32 & APHA-2500 D \\
\hline Total phosphorus & $\mathrm{mg} / \mathrm{L}$ & 10 & 0.526 & 0.49 & 5.26 & 0.05 & 1.43 & APHA-4500 \\
\hline Total hardness & $\mathrm{mg} / \mathrm{L}$ & 10 & 69.7 & 35.03 & 697 & 15 & 119 & APHA-2340 \\
\hline Total alkalinity & $\mathrm{mg} / \mathrm{L}$ & 10 & 101.08 & 39.66 & 1010.8 & 22.1 & 152 & APHA-2320 \\
\hline Calcium & $\mathrm{mg} / \mathrm{L}$ & 10 & 20.868 & 10.55 & 208.68 & 10.01 & 45.6 & APHA-3500 \\
\hline Magnesium & $\mathrm{mg} / \mathrm{L}$ & 10 & 4.607 & 2.58 & 46.07 & 1.7 & 8.12 & APHA-3500 \\
\hline Sodium & $\mathrm{mg} / \mathrm{L}$ & 10 & 9.313 & 3.69 & 93.13 & 4.43 & 16.38 & APHA-3500 \\
\hline $\mathrm{DO}$ & $\mathrm{mg} / \mathrm{L}$ & 10 & 4.075 & 1.77 & 40.75 & 2.08 & 6.67 & APHA-4500 \\
\hline
\end{tabular}

TABle 3: Correlation matrix of twelve different physicochemical parameters.

\begin{tabular}{|c|c|c|c|c|c|c|c|c|c|c|c|c|}
\hline & EC & Color & TDS & $\mathrm{Cl}$ & $\mathrm{F}$ & $\mathrm{TP}$ & $\mathrm{TH}$ & TA & $\mathrm{Ca}$ & $\mathrm{Mg}$ & $\mathrm{Na}$ & DO \\
\hline $\mathrm{EC}$ & 1 & & & & & & & & & & & \\
\hline Color & $0.849^{*}$ & 1 & & & & & & & & & & \\
\hline TDS & $1^{*}$ & $0.849^{*}$ & 1 & & & & & & & & & \\
\hline $\mathrm{Cl}$ & $0.934^{*}$ & $0.741^{* *}$ & $0.934^{*}$ & 1 & & & & & & & & \\
\hline $\mathrm{F}$ & $0.791^{*}$ & $0.856^{*}$ & $0.791^{*}$ & $0.682^{* *}$ & 1 & & & & & & & \\
\hline TP & $0.966^{*}$ & $0.821^{*}$ & $0.966^{*}$ & $0.913^{*}$ & $0.777^{*}$ & 1 & & & & & & \\
\hline $\mathrm{TH}$ & $0.933^{*}$ & $0.800^{*}$ & $0.933^{*}$ & $0.834^{*}$ & $0.772^{*}$ & $0.916^{*}$ & 1 & & & & & \\
\hline TA & $0.696^{* *}$ & $0.554^{* *}$ & $0.696^{* *}$ & $0.689^{* *}$ & 0.512 & $0.754^{* *}$ & $0.864^{*}$ & 1 & & & & \\
\hline $\mathrm{Ca}$ & $0.762^{*}$ & 0.397 & $0.762^{*}$ & $0.755^{* *}$ & $0.585^{* *}$ & $0.792^{*}$ & $0.766^{*}$ & $0.707^{*}$ & 1 & & & \\
\hline $\mathrm{Mg}$ & $0.802^{*}$ & $0.833^{*}$ & $0.802^{*}$ & $0.632^{* *}$ & $0.628^{* *}$ & $0.699^{* *}$ & $0.817^{*}$ & $0.556^{* *}$ & 0.34 & 1 & & \\
\hline $\mathrm{Na}$ & $0.738^{* *}$ & $0.558^{* *}$ & $0.738^{* *}$ & $0.808^{*}$ & $0.743^{* *}$ & $0.745^{* *}$ & $0.649^{* *}$ & 0.451 & $0.675^{* *}$ & 0.366 & 1 & \\
\hline DO & $-0.682^{* *}$ & $-0.622^{* *}$ & $-0.682^{* *}$ & -0.531 & $-0.589^{* *}$ & $-0.560^{* *}$ & -0.507 & -0.111 & -0.353 & $-0.723^{* *}$ & -0.384 & 1 \\
\hline
\end{tabular}

${ }^{*} p \leq 0.01 ;{ }^{* *} p \leq 0.1$.

TABLE 4: Linear regression equations of different physicochemical parameters and EC.

\begin{tabular}{|c|c|c|c|c|c|c|}
\hline SN & Regression equation $Y=b X+a$ & Adjusted $R^{2}$ & $p$ value & $\begin{array}{c}\text { Theoretical } \\
\text { value of } X(\mathrm{EC})\end{array}$ & $\begin{array}{l}\text { Calculated } \\
\text { value of } Y\end{array}$ & $\begin{array}{c}\text { Percentage } \\
\text { contribution to EC }\end{array}$ \\
\hline 1 & Color $=0.01226 \times \mathrm{EC}-0.54967$ & 0.6857 & 0.0019 & 500 & 5.58 & 0.88 \\
\hline 2 & $\mathrm{TDS}=0.5 \times \mathrm{EC}$ & 1.0000 & 0 & 500 & 250 & 39.6 \\
\hline 3 & $\mathrm{Cl}=0.09155 \times \mathrm{EC}-4.7422$ & 0.85641 & 0.000077 & 500 & 41.03 & 6.50 \\
\hline 4 & $\mathrm{~F}=4.189 \times 10^{-4} \times \mathrm{EC}+0.0739$ & 0.57978 & 0.0064 & 500 & 0.28 & 0.045 \\
\hline 5 & $\mathrm{TP}=0.00338 \times \mathrm{EC}-0.35428$ & 0.92554 & 0.000005 & 500 & 1.30 & 0.21 \\
\hline 6 & $\mathrm{TH}=0.2334 \times \mathrm{EC}+8.9018$ & 0.85413 & 0.000082 & 500 & 125.60 & 19.9 \\
\hline 7 & $\mathrm{TA}=0.19725 \times \mathrm{EC}+49.7127$ & 0.42037 & 0.025 & 500 & 148.34 & 23.51 \\
\hline 8 & $\mathrm{Ca}=0.05738 \times \mathrm{EC}+5.9240$ & 0.52763 & 0.0105 & 500 & 34.57 & 5.48 \\
\hline 9 & $\mathrm{Mg}=0.0147 \times \mathrm{EC}+0.7559$ & 0.599 & 0.0052 & 500 & 8.11 & 1.28 \\
\hline 10 & $\mathrm{Na}=0.0195 \times \mathrm{EC}+4.2361$ & 0.48862 & 0.0147 & 500 & 13.99 & 2.22 \\
\hline 11 & $\mathrm{DO}=-0.0086 \times \mathrm{EC}+6.3272$ & 0.39863 & 0.030 & 500 & 2.03 & 0.32 \\
\hline
\end{tabular}

of algae and aquatic plants. However, there is no recommended value of phosphorus for drinking purpose in Nepal. Among the five rivers, Haat Khola contained the highest average amount of total phosphorus $(1.25 \mathrm{mg} / \mathrm{L})$ followed by Dipeni $(0.67 \mathrm{mg} / \mathrm{L})$. It may be due to the domestic and municipal waste in the water. The lowest amount was observed in the Dhukure Khola $(0.085 \mathrm{mg} / \mathrm{L})$. The hardness of water is caused by the bicarbonate, sulphate, and chloride of calcium and magnesium. The average value of total hardness ranged from 23 to $116 \mathrm{mg} / \mathrm{L}$, and these average values showed that Ratuwa, Dipeni, and Haat Khola were moderately hard but Betani and Dhukure Khola were moderately soft. Total hardness in Haat Khola may be due to a mixing of domestic and municipal effluents whereas total hardness level in the Ratuwa River may be due to the accumulation of the natural salts from soils and rocks [29].

Among the calcium and magnesium content, calcium concentration is relatively higher than that of magnesium. The average calcium concentration ranged from 11.41 to $33.82 \mathrm{mg} / \mathrm{L}$ with SD 10.55 while magnesium from 1.82 to 
$6.0 \mathrm{mg} / \mathrm{L}$ with $\mathrm{SD} 2.58$. The calcium concentration is very low as compared to the NDWQS guideline $(200 \mathrm{mg} / \mathrm{L})$ for the drinking purpose. However, there was no recommended value of magnesium content.

Dissolved oxygen (DO) measures the amount of oxygen dissolved naturally in water. For aquatic ecosystem and metabolic activities of microorganism, DO value should be greater than $4 \mathrm{mg} / \mathrm{L}$ and for drinking purpose $6 \mathrm{mg} / \mathrm{L}$. In our samples, average DO value was 4.72, 2.57, 3.98, 4.35, and $4.77 \mathrm{mg} / \mathrm{L}$ in Ratuwa, Haat Khola, Dipeni, Betani, and Dhukure, respectively. Comparatively higher value of EC and low DO content in Haat Khola and Dipeni showed the mild pollution river as a result of organic or inorganic waste in a low volume of water [30].

Sodium content of all analyzed samples varied from $4.43 \mathrm{mg} / \mathrm{L}$ to $16.38 \mathrm{mg} / \mathrm{L}$ with $\mathrm{SD}$ of 3.69 . The maximum sodium content was observed in Haat Khola $(13.06 \mathrm{mg} / \mathrm{L})$ and Betani $(10.86 \mathrm{mg} / \mathrm{L})$. The variation in chlorine also followed the same pattern in these rivers but their concentrations $\left(\mathrm{Na}^{+}\right.$and $\left.\mathrm{Cl}^{-}\right)$did not satisfy $1: 1$ ratio in water. It indicates that there is not only one source of origin of these ions. Natural and anthropogenic sources are responsible for the higher concentration of $\mathrm{Cl}^{-}$irrespective to $\mathrm{Na}^{+}$concentration [19].

Fluoride is naturally present in river water and its presence prevents dental caries and bone damage. But its higher concentration causes dental fluorosis, and even higher concentration causes skeletal fluorosis [31]. In all samples, fluoride concentration was above the detection limit of an instrument $(>0.05 \mathrm{mg} / \mathrm{L})$ and within the permissible limit $(0.5-1.5 \mathrm{mg} / \mathrm{L})$ of the Nepal standards prescribed by NDWQS except in Dhukure where it was within the detection limit $(0.05 \mathrm{mg} / \mathrm{L})$.

Total alkalinity is a measure of all alkaline substances dissolved in the water such as carbonates, bicarbonates, and hydroxides. The highest value of TA was observed in Haat Khola $(139.4 \mathrm{mg} / \mathrm{L})$ followed by Dipeni $(117.4 \mathrm{mg} / \mathrm{L})$ and Betani $(110.5 \mathrm{mg} / \mathrm{L})$, respectively. The least value was recorded in Dhukure where its concentration was only $22.1 \mathrm{mg} / \mathrm{L}$. The permissible range is not recommended for drinking purpose in Nepal.

3.2. Percentage Contribution to EC. A correlation matrix of twelve parameters, namely, color, EC, TDS, chloride, fluoride, total phosphorus (TP), total hardness $(\mathrm{TH})$, total alkalinity (TA), calcium, magnesium, sodium, and dissolved oxygen (DO), was constructed and is shown in Table 3. The correlation coefficient always measures the relationship between the dependent and independent variables. If the correlation coefficient is +1 or -1 , it shows the perfect linear relationship between the variables.

There was strong positive and negative correlation among various physicochemical parameters. Color exhibited significant positive correlation with TDS $(r=0.849)$, F $(r=0.856)$, TP $(r=0.821), \quad \mathrm{TH} \quad(r=0.800)$, and $\mathrm{Mg}$ $(r=0.833)$ and moderate positive correlation with $\mathrm{Cl}$ $(r=0.741)$, TA $(r=0.554)$, and $\mathrm{Na}(r=0.558)$. Hence, it confirmed that these parameters were responsible to change the color of the water except calcium as it was extremely weak correlation with color $(r=0.397)$. Another fairly good positive correlation of EC was noticed with color $(r=0.849)$, TDS $(r=1), \mathrm{Cl}(r=0.934), \mathrm{F}(r=0.791)$, TP $(r=0.966)$, $\mathrm{TH} \quad(r=0.933), \mathrm{Ca} \quad(r=0.762)$, and $\mathrm{Mg} \quad(r=0.802)$. Similarly, it was moderately positive correlated with $\mathrm{TA}(r=0.696)$ and $\mathrm{Na}(r=0.738)$. These parameters strongly contributed to change the electrical conductivity of water. A good positive correlation between Cl-TP $(r=0.913), \mathrm{Cl}-\mathrm{TH}$ $(r=0.834)$, and $\mathrm{Cl}-\mathrm{Na}(r=0.808)$ was observed with significant level $p \leq 0.01$. A moderate positive correlation between $\mathrm{Cl}-\mathrm{F}(r=0.682)$, Cl-TA $(r=0.689)$, Cl-Ca $(r=0.755)$, and Cl-Mg $(r=0.632)$ also had been observed with significant level $0.01 \leq p \leq 0.1$. Another cation, fluoride showed significant correlation only with TP $(r=0.777)$ and TH $(r=0.772)$ and moderate positive correlation with $\mathrm{Ca}(r=0.585), \mathrm{Mg}$ $(r=0.628), \mathrm{Na}(r=0.743)$, and $\mathrm{Mg}(r=0.81)$ with significant level $0.01 \leq p \leq 0.1$.

Total phosphorus also depicted the fairly positive linear correlation with $\mathrm{TH}(r=0.916)$ and $\mathrm{Ca}(r=0.792)$ and a moderate positive correlation with TA $(r=0.754)$, Ca $(r=0.699)$, and $\mathrm{Na}(r=0.745)$. A moderate negative correlation of TP with $\mathrm{DO}$ indicates that $\mathrm{TP}$ content always reduces the DO value of water. The reason for it is as follows: the total phosphorus always provides the nutrient for the growth of algae and aquatic plants. If an excess of phosphorus is present in the water, algae and aquatic plants will grow wildly and consume large amounts of DO causing eutrophication. Total hardness showed the significant correlation with TA $(r=0.864), \mathrm{Ca}(r=0.766)$, and $\mathrm{Mg}$ $(r=0.817)$ while total alkalinity also demonstrated the significant correlation with $\mathrm{Ca} \quad(r=0.707)$ and $\mathrm{Mg}$ $(r=0.556)$.

In contrast, $\mathrm{DO}$ had moderately negative correlation with color $(r=-0.622)$, EC $(r=-0.682)$, TDS $(r=-0.682)$, $\mathrm{F}(r=-0.589)$, TP $(r=-0.560)$, and $\mathrm{Mg}(r=-0.723)$ and very weak correlation with $\mathrm{Cl}(r=-0.531)$, TH $(r=-0.507)$, $\mathrm{TA}(r=-0.111), \mathrm{Ca}(r=-0.353)$, and $\mathrm{Na}(r=-0.384)$ with significant level $p \geq 0.1$. These parameters are responsible to decrease $\mathrm{DO}$ value in water.

After developing the correlation coefficient matrix, scatter diagrams were constructed and shown in Figures 2 and 3, respectively. In these figures, EC was plotted along $X$-axis and others dependent parameters along $Y$-axis. The slope, $Y$-interception and adjusted $R^{2}$ of each linear best fit were shown in the inset of each figure. Similarly, a regression equation was also formulated from the pairs and depicted in Table 4 . The adjusted $R^{2}$ tells us whether the repressor is good at explaining or predicting the values of the dependent variable in the samples [32]. The higher the value of adjusted $R^{2}$, the better is the fit of data points and more useful the regression variables. The adjusted $R^{2}$ between TDS and EC is 1 , and it indicates that all data points perfectly fit in the given regression line and significance of the equations was indicated by $p$ value.

To calculate the percentage contribution to EC, a known value of EC $(500 \mu \mathrm{s} / \mathrm{cm})$ was considered in the linear regression equations shown in Table 4 and a dependent variable ( $Y$-value), as well as its percentage contribution to 


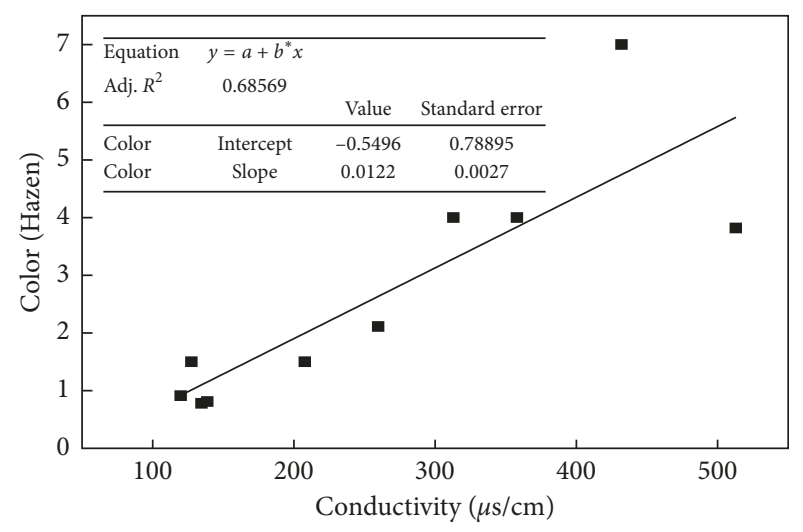

(a)

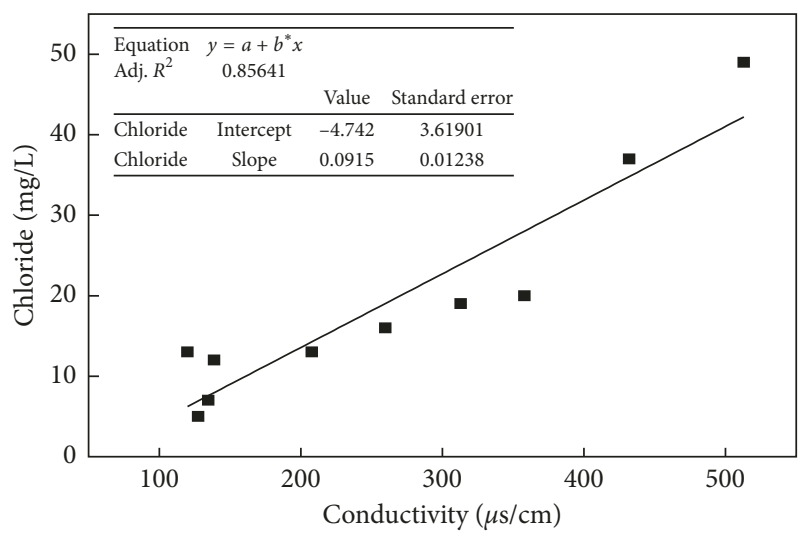

(c)

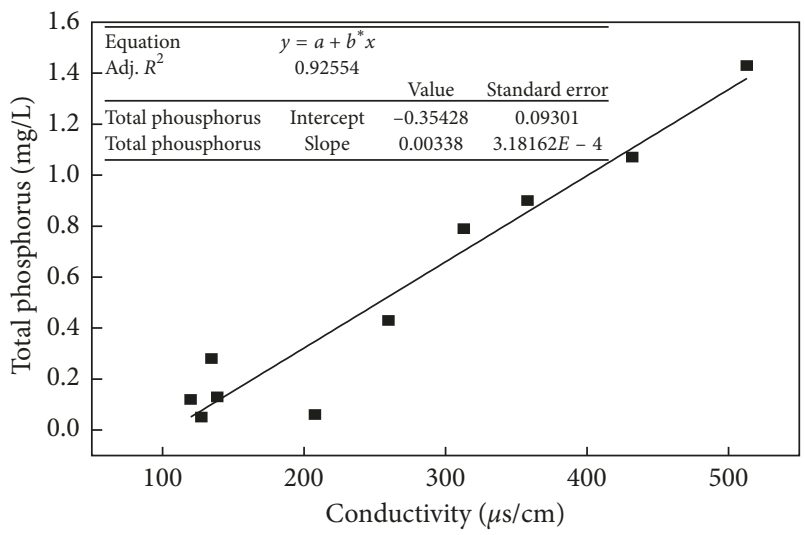

(e)

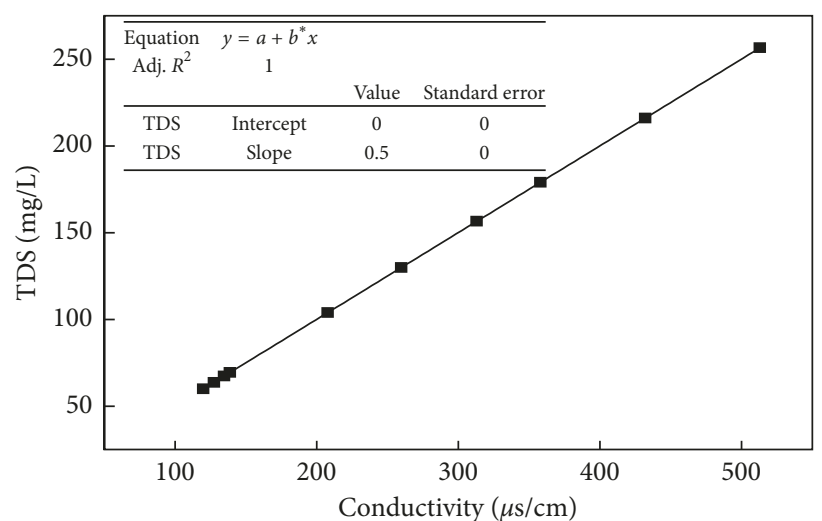

(b)

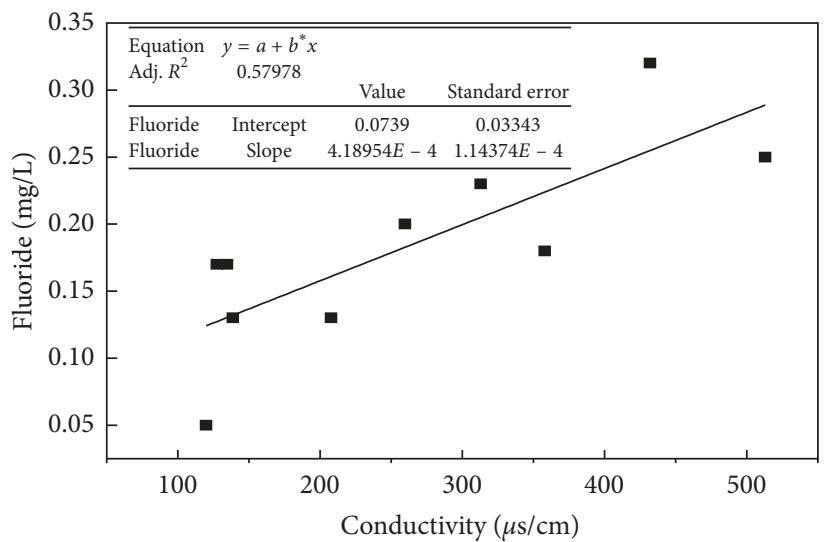

(d)

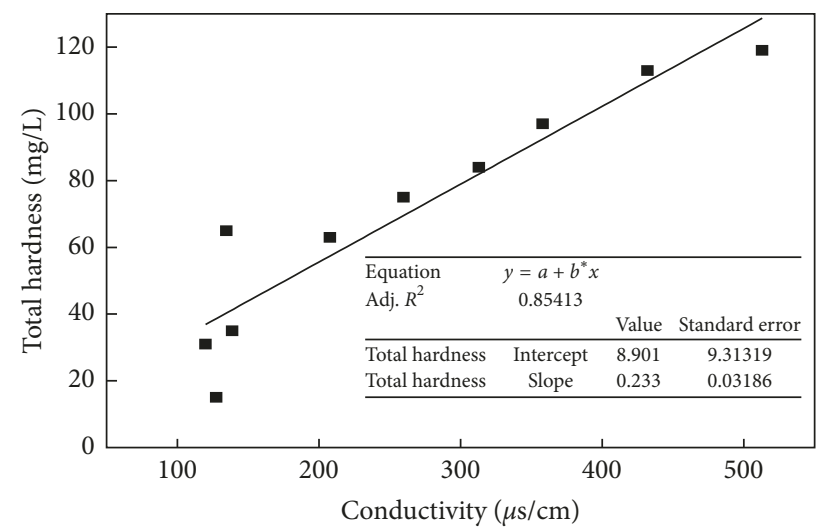

(f)

FIGURE 2: Correlation of color, TDS, chloride, flouride, total phosphorus, and total hardness with electrical conductivity.

EC were calculated [33]. The percentage contribution of each parameter to EC is presented in Figure 4. The result showed that the highest percentage contribution of TDS to EC was $39.6 \%$. Second and third highest contribution was $23.5 \%$ and $19.9 \%$ by total alkalinity and total hardness, respectively. To obtain the known value of EC, calcium and chloride also contributed $5.48 \%$ and $6.50 \%$, respectively, while sodium showed $2.2 \%$ and magnesium, $1.3 \%$ contribution. The higher contribution to EC by these independent parameters might be due to a high degree of correlation and higher concentration in water. The least percentage contribution was obtained by the parameters such as color, TP, F, and DO. Each of these parameters had less than $1 \%$ contribution, and it was due to either a low degree of correlation or less concentration in water.

\section{Conclusion}

The result of the measured twelve physicochemical parameters of Damak-based rivers demonstrates that they are in the permissible range of drinking water except the value of color in Haat Khola (7 Hazen). Comparatively higher 


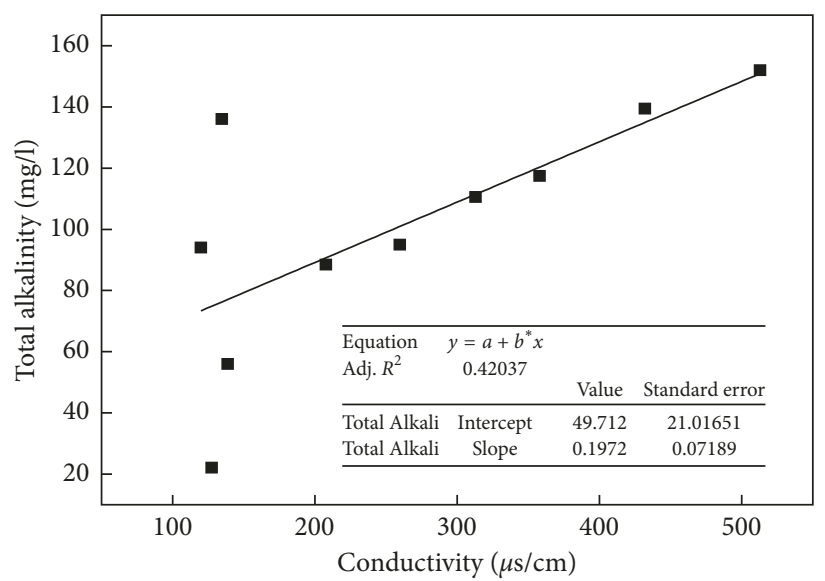

(a)

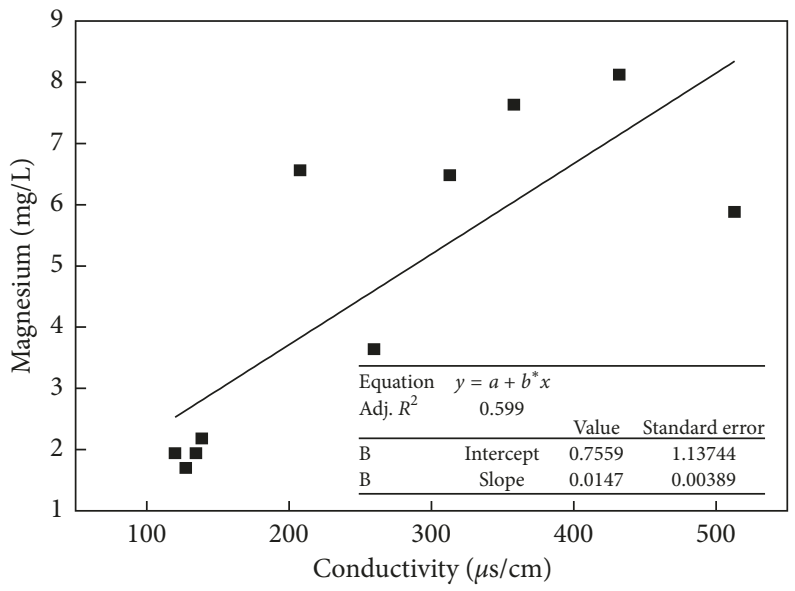

(c)

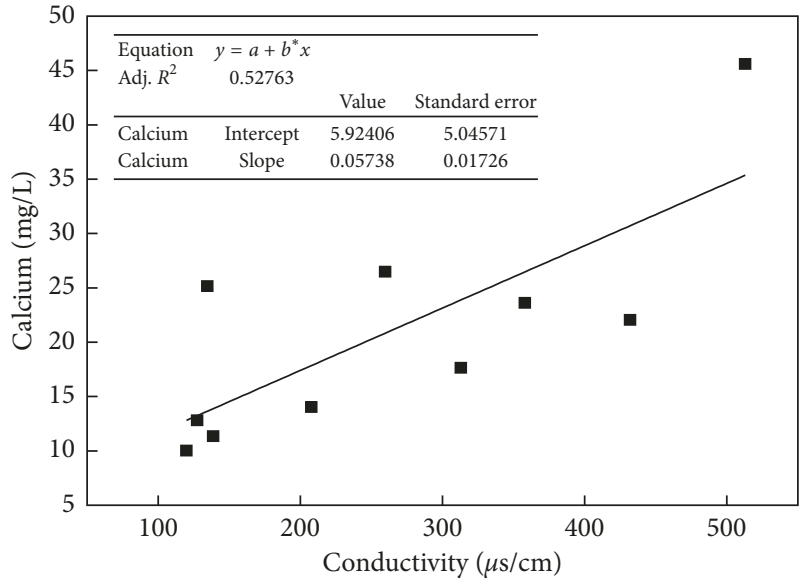

(b)

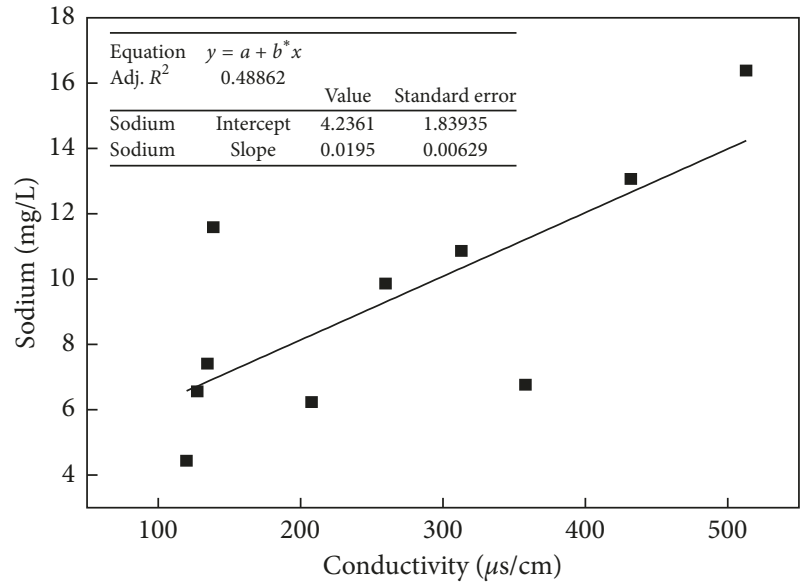

(d)

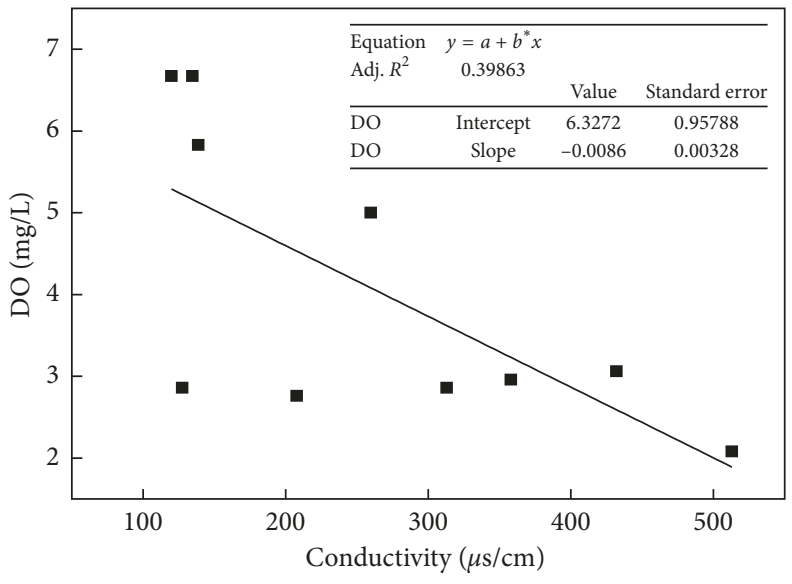

(e)

FIgURE 3: Correlation of total alkalinity, calcium, magnesium, sodium, and DO with electrical conductivity.

value of EC and other parameters and low value of DO indicates the mild pollution of Haat Khola and Dipeni. A very strong correlation of EC with color, TDS, Cl, F, TP, $\mathrm{TH}, \mathrm{Ca}$, and $\mathrm{Mg}$ and moderate correlation with $\mathrm{TA}, \mathrm{Na}$, and DO are observed. When all these parameters are treated independently for the calculation of percentage contribution to EC, it is found that TDS has the highest contribution (39.6\%) while TA has second highest contribution (23.5\%) followed by TH (19.9\%). Calcium and chloride ions also have a significant contribution and 


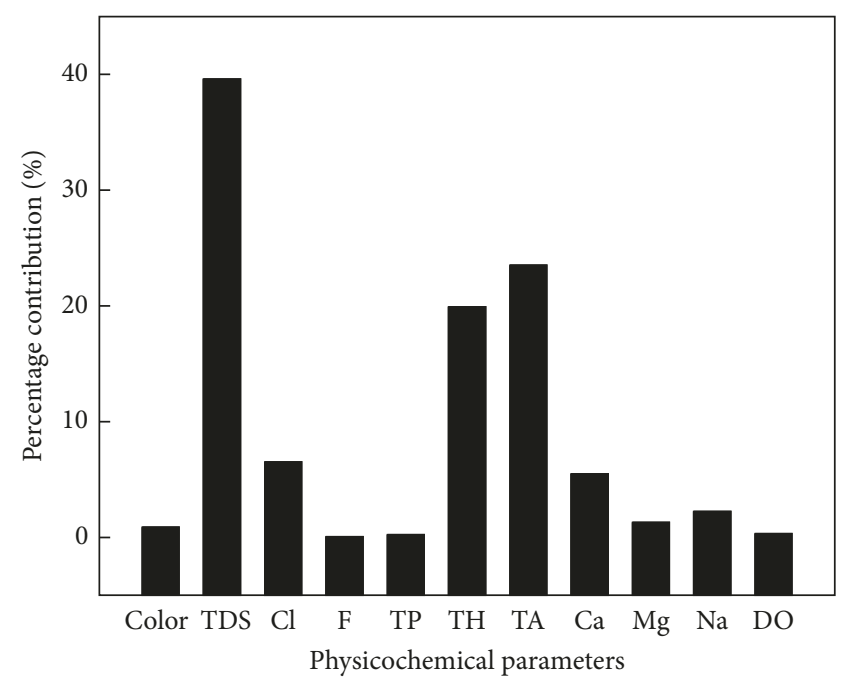

Figure 4: Percentage contribution of various parameters on the electrical conductivity.

occupy the fourth and fifth ranks. When sodium shows $2.22 \%$ contribution, magnesium only shows $1.28 \%$ contribution. Rest of the measured parameters has almost $1.45 \%$ contribution only.

\section{Data Availability}

The data used to support the findings of this study are available from the corresponding author upon request.

\section{Disclosure}

The paper was presented in the International Chemical Congress (ICC-2018) held in Sauraha, Nepal.

\section{Conflicts of Interest}

The authors declare that there are no conflicts of interest regarding the publication of this paper.

\section{Acknowledgments}

This work is a part of the project SRDIG for 2016 granted by the University Grants Commission, Nepal. So, the authors would like to pay their high gratitude to UGC, Nepal, for providing the grant to support their work. The authors are also thankful to Dr. Ajaya Bhattarai, Department of Chemistry, Mahendra Morang Aadarsha Multiple Campus (TU), for necessary help.

\section{References}

[1] N. S. Bhandari and K. Nayal, "Correlation study on physicochemical parameters and quality assessment of Kosi river water, Uttarakhand," E-Journal of Chemistry, vol. 5, no. 2, pp. 342-346, 2008.

[2] E. Pamer, G. Vujovic, P. Knezevic, B. Prvulovic, and G. Grubor-Lajsic, "Water quality assessment in lakes of Vojvodina," International Journal of Environmental Research, vol. 5, no. 4, pp. 891-900, 2011.
[3] D. M. Joshi, A. Kumar, and N. Agrawal, "Studies on physicochemical parameters to assess the water quality of river Ganga for drinking purpose in Haridwar district," Rasayan Journal of Chemistry, vol. 2, no. 1, pp. 195-203, 2009.

[4] S. Baral, R. Khanal, R. Joshi et al., "Water quality of wetlands in Nepal: a case study of Jagadispur reservoir Ramsar site," Jacobs Journal of Hydrology, vol. 1, no. 2, p. 10, 2016.

[5] A. K. Shrestha, N. Basnet, C. K. Bohora, and P. Khadka, "Variation of electrical conductivity of the different sources of water with temperature and concentration of electrolyte solution $\mathrm{NaCl}$," International Journal of Recent Research and Review, vol. 10, no. 3, pp. 24-26, 2017.

[6] R. Udhayakumar, P. Manivannan, K. Raghu, and S. Vaideki, "Assessment of physico-chemical characteristics of water in Tamilnadu," Ecotoxicology and Environmental Safety, vol. 134, no. 2, pp. 474-477, 2016.

[7] W. U. Anake, C. O. Ehi-Eromosele, T. O. Siyanbola, A. Edobor-Osoh, I. O. Adeniyi, and O. S. Taiwo, "Physicochemical and microbial assessment of different water sources in Ota, Ogun state, Nigeria," International Journal of Current Research, vol. 5, no. 7, pp. 1797-1801, 2013.

[8] P. N. Tshibangu, S. N. Ndwandwe, and E. D. Dikio, "Density, viscosity and conductivity study of 1-butyl-3-methylimidazolium bromide," International Journal of Electrochemical Science, vol. 6, no. 6, pp. 2201-2213, 2011.

[9] H. Golnabi, M. R. Matloob, M. Bahar, and M. Sharifian, "Investigation of electrical conductivity of different water liquides and elctrolyte solutions," Iranian Physical Journal, vol. 3-2, pp. 24-28, 2009.

[10] F. Ozcep, O. Tezel, and M. Asci, "Correlation between electrical resistivity and soil-water content: Istanbul and Golcuk," International Journal of Physical Sciences, vol. 4, no. 6, pp. 362-365, 2009.

[11] A. Bozkurt, C. Kurtulus, and H. Endes, "Measurements of apparent electrical conductivity and water content using a resistivity meter," International Journal of Physical Sciences, vol. 4, no. 12, pp. 784-795, 2009.

[12] R. Gautam, J. K. Shrestha, and G. K. Shrestha, "Assessment of river water intrusion at the periphery of Bagmati river in Kathmandu valley," Nepal Journal of Science and Technology, vol. 14, no. 1, pp. 137-146, 2013.

[13] N. P. Ghimire, P. K. Jha, and G. Garavello, "Physico-chemical parameters of high-altitude rivers in the Sagarmatha (Everest) National Park, Nepal," Journal of Water Resource and Protection, vol. 5, no. 8, pp. 761-767, 2013.

[14] S. Gurung, S. Sharma, and C. M. Sharma, "A brief review on limnological status of high altitude lakes in Nepal," Journal of Wetlands Ecology, vol. 3, pp. 12-22, 2009.

[15] B. R. Jha, H. Waidbacher, S. Sharma, and M. Straif, "Study of substrate and physico-chemical base classification of the rivers of Nepal," Geo-Spatial Information Science, vol. 13, no. 1, pp. 70-76, 2010.

[16] B. K. Mishra, R. K. Regmi, F. K. Masago, Y. P. Kumar, and C. Saraswat, "Assessment of Bagmati river pollution in Kathmandu valley: scenario-based modeling and analysis for sustainable urban development," Sustainability of Water Quality and Ecology, vol. 9-10, pp. 67-77, 2017.

[17] S. Sharma, R. M. Bajracharya, B. K. Sitaula, and J. Merz, "Water quality in the Central Himalaya," Current Science, vol. 89, no. 5, pp. 774-786, 2005.

[18] J. Bhusal and P. Gyawali, "Water quality of springs in Badigad Catchment, Western Nepal," Bulletin of the Department of Geology, vol. 18, pp. 67-74, 2015. 
[19] R. Malla, S. Shrestha, S. K. Chapagain, and M. Shakya, "Physico-chemical and oxygen-hydrogen isotopic assessment of Bagmati and Bishnumati rivers and the shallow groundwater along the river corridors in Kathmandu valley, Nepal," Journal of Water Resource and Protection, vol. 7, no. 17, pp. 1435-1448, 2015.

[20] R. R. Pant, F. Zhang, F. U. Rehmana et al., "Spatiotemporal variations of hydrogeochemistry and its controlling factors in the Gandaki river basin, Central Himalaya Nepal," Science of the Total Environment, vol. 622-623, pp. 770-782, 2018.

[21] D. Thapa and J. Pal, "Physico-chemical Parameters of Koshi river at Kushaha area of Koshi Tappu wildlife reserve," Our Nature, vol. 9, no. 1, pp. 156-167, 2011.

[22] G. B. Thapa and J. Pal, "Evaluation of physico-chemical characters of Singhia and Budhi rivers in Sunsari and Morang industrial corridor, Nepal," International Journal of Advanced Research in Biological Sciences, vol. 1, no. 8, pp. 104-112, 2014.

[23] M. A. M. Joarder, F. Raihan, J. B. Alam, and S. Hasanuzzaman, "Regression analysis of ground water quality data of Sunamganj District, Bangladesh," International Journal of Environmental Research, vol. 2, no. 3, pp. 291-296, 2008.

[24] R. Paudyal, S. Kang, C. M. Sharma, L. Tripathee, and M. Sillanpää, "Variations of the physicochemical parameters and metal levels and their risk assessment in urbanized Bagmati River, Kathmandu, Nepal," Journal of Chemistry, vol. 2016, Article ID 6025905, 13 pages, 2016.

[25] B. Rimal, L. Zhang, H. Keshtkar, N. Wang, and Y. Lin, "Monitoring and modeling of spatiotemporal urban expansion and land-use/land-cover change using integrated Markov chain cellular automata model," ISPRS International Journal of Geo-Information, vol. 6, no. 288, 2017.

[26] B. Tripathi, R. Pandey, D. Raghuvanshi, H. Singh, V. Pandey, and D. N. Shukla, "Studies on the physico-chemical parameters and correlation coefficient of the river Ganga at Holy Place Shringverpur, Allahabad," IOSR Journal of Environmental Science, Toxicology and Food Technology, vol. 8, no. 10, pp. 29-36, 2014.

[27] Government of Nepal, National Drinking Water Quality Standards Implementation Guideline, 2062, Ministry of Land Reform Management, Singh Durbar, Kathmandu, Nepal, 2005.

[28] M. Al-hadithi, "Application of water quality index to assess suitability of groundwater quality for drinking purposes in Ratmao-Pathri Rao watershed, Haridwar District, India," American Journal of Sceintific and Industrial Research, vol. 3, no. 6, pp. 396-402, 2012.

[29] P. Sahu, S. Karad, S. Chavan, and S. Khandelwal, "Physicochemical analysis of Mula Mutha river, Pune," Civil Engineering and Urban Planning: An International Journal, vol. 2, no. 2, 2015.

[30] D. B. Onozeyi, “Assessment of some physico-chemical parameters of River Ogun (Abeokuta, Ogun state, Southwestern Nigeria) in comparison with National and International Standards," International Journal of Aquaculture, vol. 3, no. 15 , pp. 79-84, 2013.

[31] S. M. Rao and P. Mamatha, "Water quality in sustainable water management," Current Science, vol. 87, no. 7, pp. 942-947, 2004.

[32] A. Bhatnagar and P. Devi, "Applications of correlation and regression analysis in assessing lentic water quality: a case study at Brahmsarovar Kurukshetra, India," International Journal of Environmental Sciences, vol. 3, no. 2, pp. 813-820, 2012.
[33] C. R. Ramakrishnaiah, C. Sadashivaiah, and G. Ranganna, "Assessment of water quality index for the groundwater in Tumkur Taluk, Karnataka State, India," E-Journal of Chemistry, vol. 6, no. 2, pp. 523-530, 2009. 

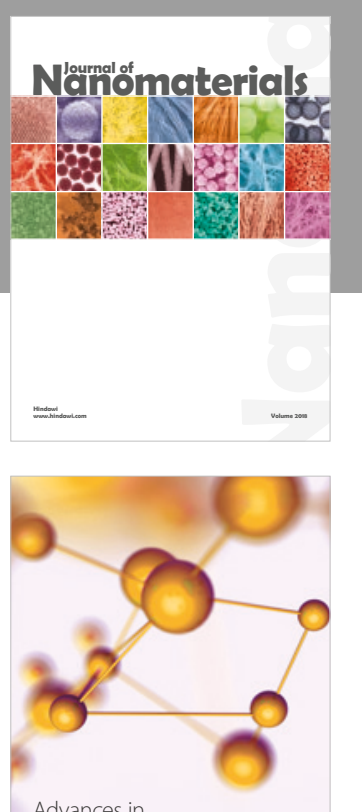

Physical Chemistry
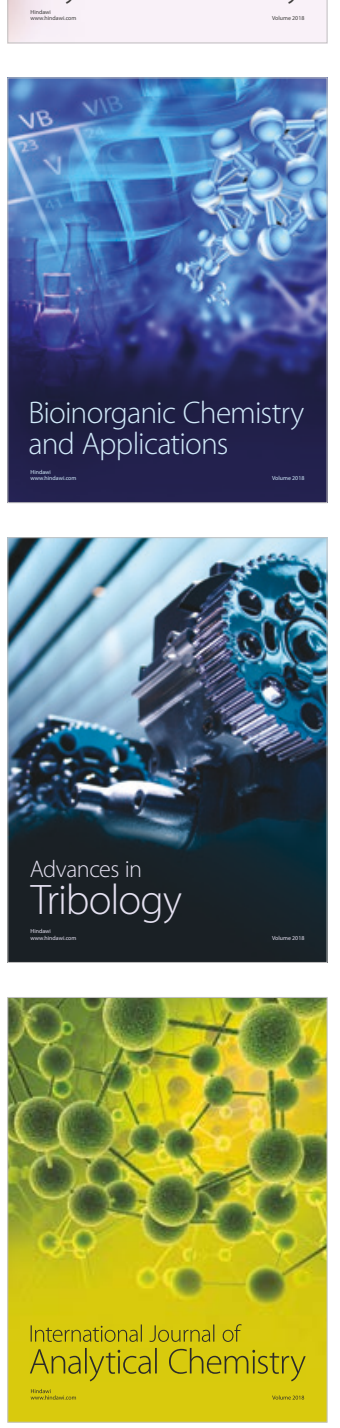

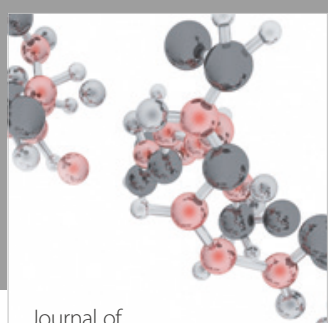

Analytical Methods

in Chemistry

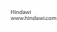

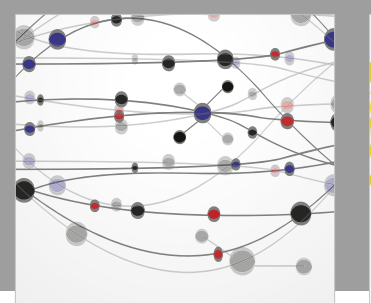

The Scientific World Journal

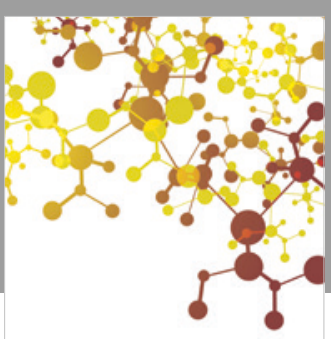

Journal of

Applied Chemistry
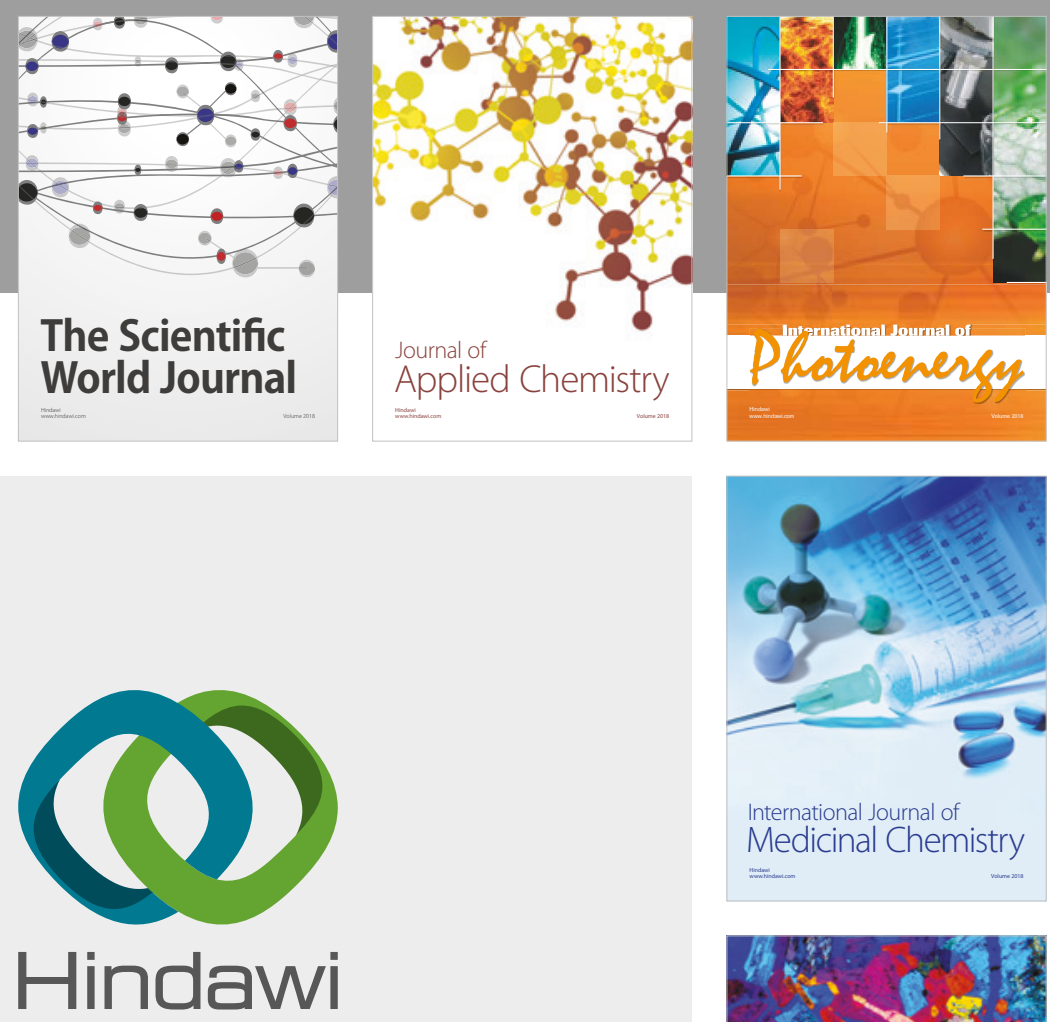

Submit your manuscripts at

www.hindawi.com
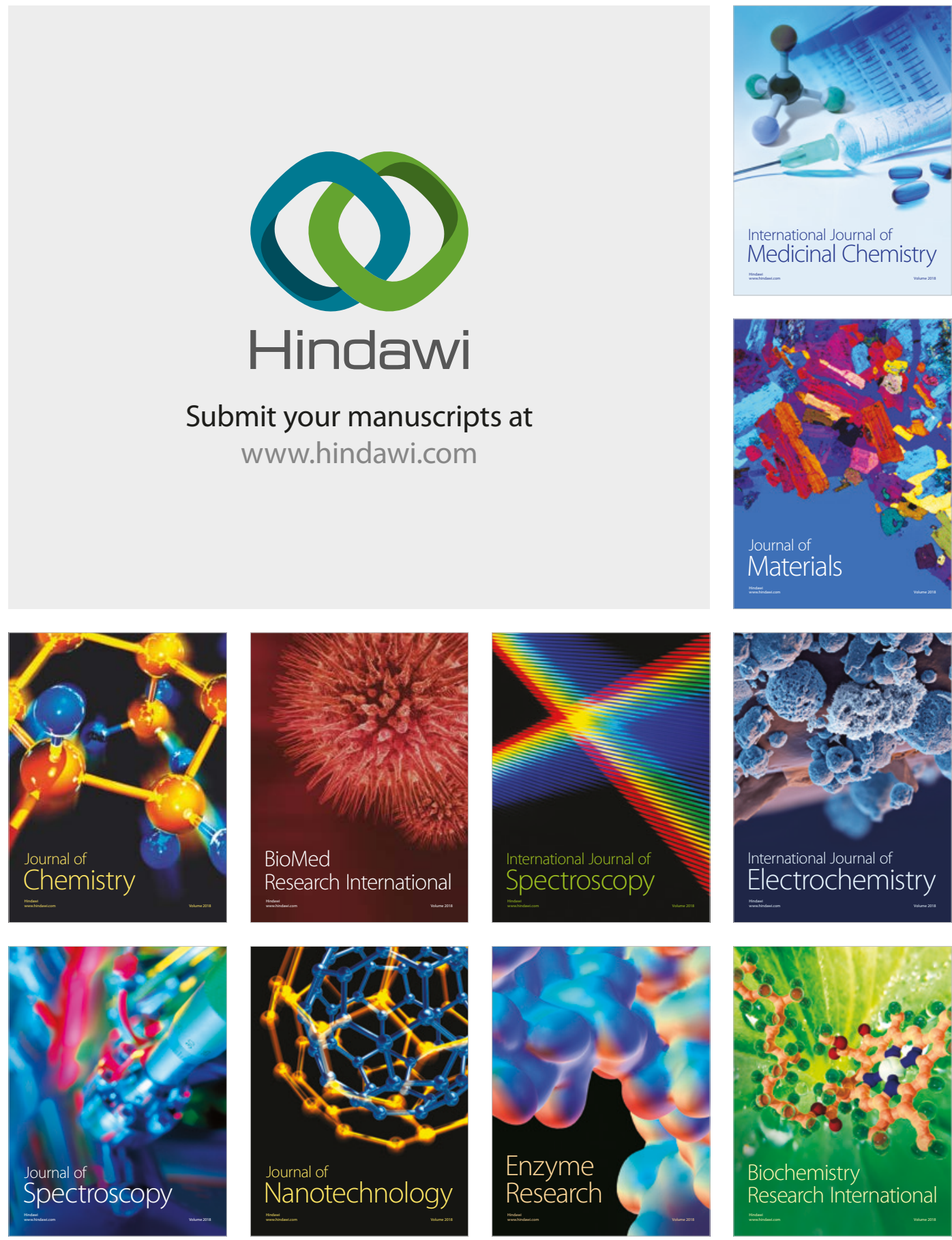
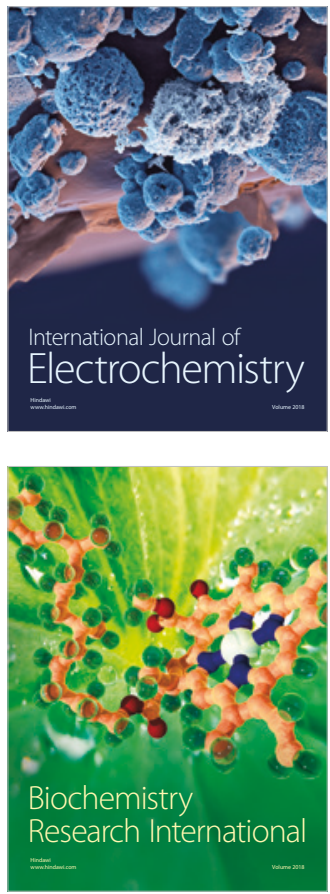